\title{
FAKTOR-FAKTOR YANG MEMPENGARUHI PERMINTAAN IKAN BANDENG (Chanos-chanos) DI PASAR PEUREULAK KABUPATEN ACEH TIMUR
}

\author{
Rozalina $^{1} /$ Bahagia $^{2}$ \\ ${ }^{1}$ Dosen Tetap Prodi Agribinis \\ ${ }^{2}$ Alumni Prodi Agribinisnis \\ Fakultas Pertanian Universitas Samudra
}

\section{RINGKASAN}

Tujuan penelitian yaitu untuk mengetahui pengaruh harga, selera dan pendapatan terhadap permintaan ikan bandeng (Chanos-chanos) di Pasar Peureulak Kabupaten Aceh Timur. Penelitian ini dilakukan di Peureulak Kabupaten Aceh Timur, dengan pertimbangan bahwa pasar Peureulak merupakan salah satu daerah pusat pembelanjaan yang banyak terdapat pedagang dan konsumen ikan bandeng. Objek penelitian ini adalah konsumen atau pembeli ikan bandeng di pasar Peureulak Kabupaten Aceh Timur. Ruang lingkup penelitian ini terbatas pada harga, selera dan pendapatan konsumen yang mempengaruhi permintaan ikan bandeng di Peureulak Kabupaten Aceh Timur.

Sampel penelitian terdiri pedagang ikan bandeng yaitu sebanyak 7 orang yang terdapat pada lorong I, II dan III, pada masing-masing pedagang di ambil 1 pedagang sampel, sehingga terkumpul 3 orang pedagang. Sampel konsumen ikan bandeng sebanyak 30 orang dari 3 pedagang sampel, pada pedagang Abdullah sebanyak 10 orang, pedagang Zulkarnaen sebanyak 11 orang dan pedagang Sulaiman sebanyak 9 orang.

Hasil penelitian: Karakteristik konsumen ikan bandeng adalah umur rata-rata konsumen ikan bandeng adalah 42,83 tahun, tingkat pendidikan rata-rata adalah 10,33 tahun (SLTA kelas I) dan jumlah tanggungan keluarga konsumen ikan bandeng rata-rata 5 orang Rata-rata permintaan konsumen ikan bandeng di Pasar Peureulak sebesar 5,4 kg/bulan, rata-rata harga ikan bandeng yang dibeli konsumen adalah Rp. 23.733,33/Kg, rata-rata skor jawaban konsumen ikan bandeng adalah 2,2 skor yang berarti selera konsumen adalah sedang menuju tinggi dan rata-rata pendapatan konsumen ikan bandeng di Pasar Peureulak adalah Rp. 2.325.000/Bulan.

Hasil analisis linier berganda diperoleh persamaan regresi sebagai berikut: $\mathrm{Y}=-1,102+$ $0,119 X_{1}+0,146 X_{2}+1,439 X_{3}$. Hasil analisis data secara regresi linier berganda menghasikan nilai $R^{2}$ sebesar 0,69 artinya bahwa variabel harga $\left(\mathrm{X}_{1}\right)$, selera konsumen $\left(\mathrm{X}_{2}\right)$ dan pendapatan konsumen $\left(\mathrm{X}_{3}\right)$ mempengaruhi permintaan ikan bandeng (Y) di Pasar Peureulak sebesar $69 \%$. Sisanya sebesar 31\% dipengaruh faktor lain yang tidak dimasukan dalam model penelitian ini. Secara serempak variabel harga $\left(\mathrm{X}_{1}\right)$, selera konsumen $\left(\mathrm{X}_{2}\right)$ dan pendapatan konsumen $\left(\mathrm{X}_{3}\right)$ secara serempak berpengaruh sangat nyata terhadap permintaan ikan bandeng (Y) di Pasar Peureulak. Secara terpisah harga dan selera konsumen tidak berpengaruh nyata terhadap permintaan ikan bandeng, sedangkan pendapatan konsumen secara terpisah berpengaruh sangat nyata terhadap permintaan ikan bandeng di Pasar Peureulak Kabupaten Aceh Timur.

Kata Kunci: Ikan Bandeng, Permintaan, Harga, Pendapatan, Selera, Konsumen

\section{PENDAHULAN \\ Latar Belakang}

Indonesia merupakan salah satu negara agraris yang sebagian besar penduduknya tinggal di pedesaan dan menggantungkan hidupnya pada sektor pertanian. Sebagai negara berkembang sektor pertanian masih memegang peranan penting dari keseluruhan nasional, hal ini dapat ditunjukkan dari banyaknya penduduk atau tenaga kerja yang hidup atau bekerja pada sektor pertanian.

Sebagai salah satu sektor pemberi konstruksi terutama sebagai pemasok bahan baku bagi industri akan membuka peluang terciptanya lapangan kerja bagi masyarakat sehingga lapangan kerja dapat terserap dan mengurangi angka pengangguran, sektor perikanan juga merupakan sektor dalam penyumbang davisa negara, pengembangan perikanan secara nasional dan terpadu khusunya komoditas perikanan komersial yang mencakup ikan dan non ikan dalam rangka peningkatan ekspor hasil perikanan.

Salah satu sumber hayati perairan bernilai ekonomis penting dan telah dibudidayakan komersial adalah ikan bandeng. Di Indonesia budidaya ikan bandeng di 
Indonesia telah lama dilakukan para produsen tambak baik secara tradisional maupun intensif. Meningkatnya konsumsi masyarakat akan bandeng menjadikan usaha budidaya ikan bandeng tahap demi tahap terus menunjukkan peningkatan. Perkembangan yang pesat dari usaha budidaya bandeng di tambak harus pula di imbangi dengan penyediaan benih (nener) secara berkesinambungan dalam jumlah yang cukup dan berkualitas prima. Hal ini dimaksudkan untuk menjamin ketersediaan bandeng sepanjang tahun pada tingkat produksi maksimal dan berkesinambungan.

Pengembangan budidaya tambak di daerah pesisir pantai perlu memperhatikan daya dukung lahan, pengembangan tambak yang melampaui daya dukung lingkungan (produktivitas) akan menimbulkan berbagai Tabel I-1 : Kandungan Gizi Bandeng (dalam berat 300 gram).

\begin{tabular}{|l|l|l|l|}
\hline No & Komponen & Nilai Gizi & Satuan \\
\hline 1. & Protein & 22,40 & Gram \\
2. & Lemak jenuh & 2,90 & Gram \\
3. & Sodium & 78,00 & Gram \\
4. & Kolestrol & 57,00 & Gram \\
5. & Vitamin B & 116,00 & Persen \\
6. & Niacin & 12,44 & Persen \\
7. & Vitamin B6 & 24,00 & Persen \\
8. & Asam pantotenat & 15,00 & Persen \\
9. & Mineral & 25,00 & Persen \\
\hline
\end{tabular}

Sumber : Sulaksono (2013:1)

Dari Tabel I-1 dapat dilihat bahwa di dalam bandeng terdapat banyak kandungan gizi yang baik untuk tubuh kita. Kandungan gizi terbesar terdapat pada vitamin B sebanyak 116,00 persen dan kandungan gizi terkecil terdapat pada asam pantotenat yaitu sebanyak 15,00 persen.

Provinsi Aceh berbatasan dengan Selat Malaka salah satu Kabupaten di Aceh adalah Aceh Timur, hal ini membuat Aceh Timur menjadi tempat strategis untuk penangkapan ikan laut . Rawa, air genangan, tambak, dan sungai juga menjadi pendukung perikanan darat. Perikananan laut yang didukung oleh pelabuhan Idi sebagai pelabuhan ikan memberikan konstribusi besar terhadap perekonomian Aceh Timur.

Hasil perikanan ini selain mengisi kebutuhan pasar lokal juga dipasarkan di pasar diluar Aceh Timur dalam bentuk segar. Kabupaten Aceh Timur sangat kaya akan sumber daya alamnya, seperti kelapa sawit, dampak ikutan seperti krisis $\mathrm{pH}$ tanah, kualitas $\mathrm{pH}$ air, salinitas air, kehidupan mikro organisme yang semakin berkurang dan sulit di atasi. Daya dukung lahan pesisir untuk pertambakan ditentukan oleh kualitas tanah, kualitas sumber air (asin dan tawar), arus pasang surut (hidrooseanografi) tofografi dan klimatologi daerah pesisir dan daerah aliran sungai di daerah hulu.

Kelemahan utama dari ikan bandeng adalah durinya yang sangat banyak, dan kadang-kadang ada yang bau seperti tanah. Ikan bandeng yang berbau tanah biasanya dibudidayakan di tambak, ada yang dibudidayakan daerah aliran yang airnya mengalir. Untuk melihat nilai gizi yang terdapat dalam bandeng dapat dilihat pada Tabel I-1 berikut ini : kayu dan padi. Selain perkebunan, perikanan tetap menjadi andalan di dukung oleh letak geografis yang membujur sepanjang pantai timur.

Ikan bandeng yang tersedia di Kecamatan Peureulak berasal dari daerah tambak Kecamatan Peureulak, sehingga kualitasnya lebih terjamin dengan harga terjangkau. Banyaknya manfaat, kandungan gizi dan permintaan akan ikan bandeng dan harganya yang terjangkau dapat menarik konsumen untuk mengkonsumsi ikan bandeng. Ikan bandeng yang terkenal dengan kandungan omega 3 nya mendapat respon konsumen yang baik untuk memenuhi kebutuhan gizi dimasa pertumbuhan anak-anak.

Konsumen yaitu setiap orang pemakai barang atau jasa yang tersedia dalam masyarakat, baik bagi diri sendiri, keluarga, orang lain maupun makhluk hidup lain dan tidak untuk diperdagangkan. Setiap konsumen berusaha untuk memenuhi kebutuhan 
hidupnya dengan pemenuhan yang maksimal. Jumlah dan keanekaragaman barang yang dapat dipenuhi bergantung pada besar pendapatan atau penghasilan. Tingkat kemakmuran dan kesejahteraan seseorang atau masyarakat bergantung pada tingkat konsumsi yang digunakan.

Permintaan adalah sejumlah barang yang dibutuhkan oleh konsumen dalam berbagai tingkatan harga. Permintaan suatu barang ditentukan oleh banyak faktor sehingga jumlah permintaan dapat meningkat dan menurun sesuai keadaan yang mempengaruhinya.

Harga merupakan salah satu variabel yang perlu diperhatikan oleh bagian pemasaran, karena harga langsung mempengaruhi besarnya volume penjualan. Kebijaksanaan perencanaan produksi, penyaluran barang dan penggunaan media promosi yang baik tidak dapat menghasilkan sesuatu bila kebijaksanaan tentang harga tidak diikutsertakan.

Selain harga, selera konsumen juga dapat mempengaruhi respon konsumen terhadap permintaan ikan bandeng. Selera konsumen berhubungan dengan keadaan barang yang diminta. Jika barang yang dijual oleh pedagang mempunyai keunggulan maka konsumen akan tertarik untuk membelinya, akan tetapi jika barang yang dijual oleh pedagang tidak menarik maka konsumen akan batal untuk membelinya.

Setelah harga dan selera konsumen, pendapatan konsumen juga dapat mempengaruhi respon kosumen terhadap permintaan ikan bandeng. Pendapatan konsumen adalah jumlah uang yang diterima oleh seseorang dari aktivitasnya. Pendapatan sangat berpengaruh bagi kelangsungan hidup keluarga, semakin besar pendapatan yang diperoleh maka semakin besar kemampuan keluarga untuk membiayai segala pengeluaran dan kegiatan-kegiatan yang akan dilakukan pada suatu rumah tangga.

$$
\text { Menurut Soekirno (2008:75-81) }
$$

faktor-faktor yang mempengaruhi permintaan suatu barang yaitu :

a. Harga barang. Jika harga maka makin tinggi maka permintaan makin rendah dan begitu sebaliknya jika harga barang rendah maka permintaan akan barang tersebut akan makin tinggi.

b. Pendapatan masyarakat; makin tinggi pendapatan seseorang maka semakin besar daya beli yang ia miliki, sehingga permintaan akan barang dan jasa pun meningkat, dan begitu juga sebaliknya jika orang berpenghasilan rendah maka permintaan akan barang dan jasa pun akan menurun.

c. Selera masyarakat. Jika selera masyarakat meningkat maka permintaan pun meningkat pula, dan begitu pula sebaliknya. Selera masyarakat sering disebut model atau tren.

d. Kualitas barang. Makin tinggi kualiatas suatu barang maka keinginan (permintaan) orang untuk dapat memiliki barang tersebut makin besar.

e. Harga barang lain yang berkaitan. Harga barang lain yang dimaksud ini adalah barang substitusi. Yaitu barang pengganti yang sama fungsinya dengan barang yang dibutuhkan.

f. Waktu. Pada waktu-waktu tertentu permintaan terhadap barang atau jasa dapat meningkat dari pada hari-hari biasa, seperti pada saat lebaran atau hari-hari besar/ istimewa yang lain.

g. Jumlah penduduk. Makin besar jumlah penduduk maka makin besar pula permintaan terhadap barang atau jasa, dan sebaliknya.

Dari penjelasan mengenai faktorfaktor yang mempengaruhi permintaan yang meliputi harga, selera dan pendapatan konsumen penulis tertarik untuk meneliti tentang faktor-faktor yang mempengaruhi permintaan ikan bandeng (Chanos-chanos) di Pasar Peureulak Kabupaten Aceh Timur.

\section{Identifikasi Masalah}

"Apakah harga, selera dan pendapatan konsumen berpengaruh terhadap permintaan ikan bandeng (Chanos-chanos) di Pasar Peureulak Kabupaten Aceh Timur".

\section{Tujuan Penelitian}

"Untuk mengetahui pengaruh harga, selera dan pendapatan konsumen terhadap permintaan ikan bandeng (Chanos-chanos) di Pasar Peureulak Kabupaten Aceh Timur".

\section{Hipotesis Penelitian}

"Harga, selera dan pendapatan konsumen berpengaruh terhadap permintaan 
ikan bandeng (Chanos-chanos) di Pasar Peureulak Kabupaten Aceh Timur".

\section{METODE PENELITIAN}

\section{Lokasi, Objek, Ruang Lingkup dan Waktu} Penelitian

Penelitian ini dilakukan dengan metode survey, menurut Nazir (2009: 56) "Metode survey adalah penyelidikan untuk memperoleh fakta dari gejala-gejala dan mencari keterangan-keterangan secara faktual baik tentang institusi sosial, ekonomi atau politik dari suatu kelompok ataupun suatu daerah". Lokasi penelitian dilakukan di Peureulak Kabupaten Aceh Timur, dengan pertimbangan bahwa pasar Peureulak merupakan salah satu daerah pusat pembelanjaan yang banyak terdapat pedagang dan konsumen ikan bandeng. Objek penelitian ini adalah konsumen atau pembeli ikan bandeng di pasar Peureulak Kabupaten Aceh

Timur. Ruang lingkup penelitian ini terbatas pada harga, selera dan pendapatan konsumen yang mempengaruhi permintaan ikan bandeng (Chanos-chanos) di Peureulak Kabupaten Aceh Timur. Waktu penelitian ini dilaksanakan pada Bulan April - Mei 2017.

\section{Teknik Penentuan Sampel dan Pengumpulan Data Penentuan Sampel}

Sampel dalam penelitian ini ialah semua konsumen yang mengkonsumsi ikan bandeng yang dibeli pada pedagang ikan bandeng di pasar Peureulak Kabupaten Aceh Timur. Menurut Nana (2005:5), “sampel merupakan sebagian dari dari populasi yang paling tidak mempunyai satu ciri yang sama dengan populasinya untuk mewakili populasi yang ada". Untuk melihat keadaan pedagang ikan bandeng di Peureulak tahun 2015 dapat dilihat pada Tabel III-1 berikut :

Tabel III-1. Jumlah Populasi dan Jumlah Sampel Pedagang Ikan bandeng di Pasar Peureulak, 2017

\begin{tabular}{|l|l|l|l|}
\hline No & Nama Tempat & Populasi & Sampel \\
\hline 1 & Lorong I & 2 & 1 \\
2 & Lorong II & 3 & 1 \\
3 & Lorong III & 2 & 1 \\
\hline \multicolumn{2}{|l|}{ Jumlah } & 7 & 3 \\
\hline
\end{tabular}

Sumber : Data Primer, 2017 (diolah)

Tabel III-1 menunjukan bahwa jumlah populasi pedagang ikan bandeng yaitu sebanyak 7 orang yang terdapat pada lorong I, II dan III, pada masing-masing pedagang di ambil 1 pedagang sampel, sehingga terkumpul 3 orang pedagang sampel ikan bandeng dari jumlah seluruhnya 7 orang.

Metode pengambilan sampel yang digunakan dalam penelitian ini adalah metode sampling insidental. Menurut Sugiyono (2010:122), "Sampling Insidental adalah teknik penentuan sampel berdasarkan kebetulan, yaitu siapa saja yang secara kebetulan/insidental bertemu dengan peneliti dapat digunakan sebagai sampel,bila dipandang orang yang kebutulan ditemui cocok sebagai narasumber data". Data lapangan akan dikumpulkan dengan menggunakan teknik sampling insidental artinya penyebaran kuisioner ditunjukkan kepada responden di jumpai langsung dipasar Peureulak pada saat membeli ikan bandeng. Sudjana, (2003:96) menyatakan : "Sebaliknya bila populasi kecil, sampel dirumuskan mendekati jumlah populasi, misalnya bila populasi sekitar 1000 kasus menarik sampel 10-20\% telah cukup memadai, namun bila populasi 50 kasus sampel tidak kurang dari 30 kasus". Pengambilan konsumen sampel dilakukan dengan mengambil $20 \%$ dari populasi konsumen pada tiap pedagang sampel, alasan pengambilan sampel $20 \%$ karena jumlah populasi sudah memadai untuk dijadikan sampel.

Tabel III-2. Jumlah Populasi dan Jumlah Sampel Konsumen Ikan Bandeng di Pasar Peureulak, 2017

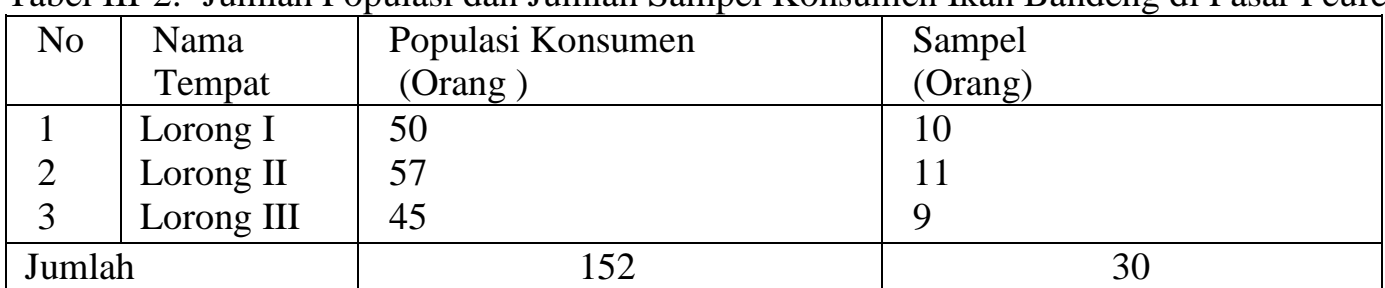

Sumber : Data Primer, 2016 (diolah) 
Tabel III-2 menunjukan bahwa jumlah populasi konsumen ikan bandeng yaitu sebanyak 152 orang dan terdapat sampel sebanyak 30 orang dari 3 pedagang sampel, pada pedagang Abdullah sebanyak 10 orang, pedagang Zulkarnaen sebanyak 11 orang dan pedagang Sulaiman sebanyak 9 orang.

\section{Variabel dan Data Yang di Analisis}

Variabel dan data yang di analisis dalam penelitian ini adalah sebagai berikut:

a. Permintaan

b. Harga

$$
\text { (Y) } \quad(\mathrm{Kg} / \mathrm{Bulan})
$$

c. Selera Konsumen

$$
\left(\mathrm{X}_{1}\right) \quad(\mathrm{Rp} / \mathrm{Kg})
$$

$\left(\mathrm{X}_{2}\right) \quad$ (Skor)

d. Pendapatan konsumen

$$
\left(\mathrm{X}_{3}\right) \quad(\mathrm{Rp} / \mathrm{Bulan})
$$

\section{Metode Analisis dan Pengujian Hipotesis}

Hipotesis yang telah dirumuskan diatas akan di uji kebenarannya dengan menggunakan analisis regresi linier berganda, dengan satu variabel dependen ( $\mathrm{Y}$ ) dan tiga variebel independen yaitu variabel $\left(\mathrm{X}_{1}, \mathrm{X}_{2}, \mathrm{X}_{3}\right)$. Menurut (Sudjana,2005:339) "analisis ini digunakan untuk mengetahui arah hubungan antara variabel independen dengan variabel dependen apakah positif atau negatif dan untuk memperdeksi nilai dari variabel dependen apabila nilai variabel independen mengalami kenaikan atau penurunan". Model tersebut dapat di tulis sebagai berikut .

$\mathrm{Y}=\mathrm{a}_{0}+\mathrm{a}_{1} \mathrm{X}_{1}+\mathrm{a}_{2} \mathrm{X}_{2}+\mathrm{a}_{3} \mathrm{X}_{3}+\mathrm{e}$. .. Sudjana, 2005:347)

Keterangan :

$\mathrm{Y}=$ Permintaan ikan banden (Kg/bulan)

$\mathrm{X}_{1}=$ Harga $(\mathrm{Rp} / \mathrm{Kg})$

$\mathrm{X}_{2} \quad=$ Selera (skor)

$\mathrm{X}_{3}=$ Pendapatan Konsumen

(Rp/Bulan)

$\mathrm{a}_{0}, \mathrm{a}_{1}$ dan $\mathrm{a}_{2} \quad=$ Koefesien regresi yang dicari

Koefisien Determinasi bertujuan untuk mengetahui seberapa besar kemampuan variabel independen menjelaskan variabel terikat. Sudjana (2005:383) menjelaskan "Koefisien determinasi $\left(\mathrm{R}^{2}\right)$ adalah keragaman atau variansi total nilai peubah $\mathrm{Y}$ yang dapat dijelaskan oleh nilai peubah $\mathrm{X}$ melalui hubungan linier". digunakan koefisien determinasi $\left(\mathrm{R}^{2}\right)$, dengan rumus:

$$
R^{2}=\frac{J K r e g}{\sum y^{2}} \ldots . .(\text { Sudjana, } 2005: 383)
$$

Dimana :

$\mathrm{R}^{2} \quad=$ Koefisien Determinasi ( persentase hubungan $\mathrm{X}_{1}$ dan $\mathrm{X}_{2}$ terhadap $\mathrm{Y}$ )

$\mathrm{JK}_{\text {reg }} \quad=$ Jumlah Kuadrat Regresi

$\Sigma \mathrm{y}^{2} \quad$ Jumlah Kuadrat Total

Untuk menguji secara serempak

pengaruh variabel bebas $\left(\mathrm{X}_{1}, \mathrm{X}_{2}\right.$ dan $\left.\mathrm{X}_{3}\right)$ terhadap variabel terikat (Y), digunakan uji $\mathrm{F}$ (Sudjana, 2005:355) menjelaskan "uji f adalah metode pengujian yang dilakukan untuk mengetahui pengaruh variabel bebas secara bersama-sama terhadap variabel terikat". Digunakan rumus sebagai berikut :

$$
F=\frac{J K_{r e g} / k}{J K_{r e s} /(n-k-1)} \ldots(\text { Sudjana, 2005:355) }
$$

Dimana:

$\mathrm{JK}_{\text {reg }}=$ Jumlah kuadrat-kuadrat untuk regresi

$\mathrm{k}=$ Banyaknya variebel bebas

$\mathrm{JK}_{\text {res }}=$ Jumlah kuadrat-kuadrat residu

$\mathrm{n} \quad=$ Jumlah sampel

Dengan ketentuan :

$\mathrm{F}_{\text {hit }}>\mathrm{F}$ tabel, pada taraf $0,05=95 \%$ dan $0,01=$ 99\%, maka terima Ha tolak $\mathrm{H}_{0}$

$\mathrm{F}_{\text {hit }}>\mathrm{F}$ tabel, pada taraf $0,05=95 \%$ dan $0,01=$ 99\%, maka tolak Ha terima $\mathrm{H}_{0}$

Untuk mengetahui pengaruh secara parsial digunakan uji $\mathrm{t}$ untuk pengujian. Sudjana, (2005:388) menjelaskan "uji t adalah metode pengujian yang dilakukan untuk mengetahui pengaruh variabel bebas sacara individual terhadap variabel terikat ". Dengan rumus sebagai berikut:

thit $=\frac{a i}{S a i}$ .(Sudjana,

2005:388)

Keterangan :

$\mathrm{t}=\mathrm{Uji}$ secara terpisah (parsial)

ai $\quad=$ Koefisien regresi yang dicari

Sai $\quad=$ Standar error dari koefisien regresi

Uji parsial (Uji t) bertujuan untuk mengetahui besarnya pengaruh masing-masing variabel independen secara individual (parsial) terhadap variabel dependen.

Dengan ketentuan pengambilan keputusan: $\mathrm{t}_{\text {hit }}>\mathrm{t}_{\text {tabel }}$, pada taraf $0,05=95 \%$ dan $0,01=$ 99\%, maka terima Ha tolak Ho 
$\mathrm{t}_{\text {hit }}>\mathrm{t}_{\text {tabel }}$, pada taraf $0,05=95 \%$ dan $0,01=$ 99\%, maka tolak Ha terima Ho

dimana :

\section{HASIL PENELITIAN DAN \\ PEMBAHASAN \\ Karakteristik Konsumen Ikan Bandeng}

Karakteristik konsumen ikan bandeng dalam penelitian ini meliputi umur, pendidikan dan jumlah tanggungan keluarga. Rini Tabel V-1. Rata-rata Karakteristik Konsumen Ikan Bandeng di Pasar Peureulak, 2017

\begin{tabular}{|l|l|c|c|c|}
\hline No & $\begin{array}{c}\text { Konsumen Dari } \\
\text { Pedagang }\end{array}$ & $\begin{array}{c}\text { Umur } \\
\text { (Tahun) }\end{array}$ & $\begin{array}{c}\text { Pendidikan } \\
\text { (Tahun) }\end{array}$ & $\begin{array}{c}\text { Jumlah Tanggungan } \\
\text { Keluarga (Orang) }\end{array}$ \\
\hline 1 & Lorong I & 40.70 & 10.00 & 5.10 \\
2 & Lorong II & 43.91 & 9.55 & 5.27 \\
3 & Lorong III & 43.89 & 11.67 & 4.89 \\
\hline & Rata-Rata & 42.83 & 10.33 & 5.00 \\
\hline
\end{tabular}

Sumber : Data Primer, 2017 (diolah)

Tabel V-1 di atas menjelaskan bahwa umur rata-rata konsumen ikan bandeng adalah 42,83 tahun, umur tersebut adalah umur yang produktif dalam bekerja untuk menafkahi keluarganya. Tingkat pendidikan rata-rata adalah 10,33 tahun (SLTA kelas I), pendidikan konsumen ikan bandeng tergolong sedang. Semakin tinggi tingkat pendidikan seorang konsumen, maka semakin kreatif konsumen tersebut dalam mengambil keputusan dalam membeli suatu barang, begitu juga sebaliknya semakin rendah tingkat pendidikan konsumen maka semakin lambat dalam mengambil berbagai keputusan dalam membeli suatu barang. Jumlah tanggungan keluarga konsumen ikan bandeng rata-rata 5 orang, menunjukkan bahwa jumlah tanggungan keluarga rata-rata 5 orang merupakan tanggungan yang sedang sehingga konsumen ikan bandeng mempunyai beban yang agak berat membeli ikan bandeng dalam jumlah yang banyak.

Pekerjaan yang dimaksud dalam penelitian ini adalah pekerjaan utama dari
(2005:26), "pengertian karakteristik individu adalah bagian dari pribadi dan melekat pada diri seseorang. Karakteristik ini mendasari tingkah laku seseorang dalam situasi kerja maupun situasi yang lainnya". Karakteristik akan mempengaruhi respon konsumen ikan bandeng dalam membeli ikan bandeng.

Karakteristik konsumen ikan bandeng di Pasar Peureulak dapat dilihat pada tabel V-1 berikut ini. konsumen ikan bandeng yang dijadikan sampel penelitian. Pekerjaan konsumen ikan bandeng di Pasar Peureulak terdiri dari petani sebanyak 13 orang $(43,33 \%)$, pedagang sebanyak 6 orang (20\%), guru swasta sebanyak 1 orang $(3,33 \%)$, PNS sebanyak 4 orang $(13,33 \%)$, buruh bangunan sebanyak 2 orang $(6,67 \%)$ dan karyawan swasta sebanyak 4 orang $(13,33 \%)$.

\section{Hasil Rekapitulasi Jawaban Kuisioner Konsumen Ikan Bandeng Atas Masing- Masing Variabel Penelitian}

\section{Permintaan Konsumen}

Permintaan ikan bandengan adalah banyaknya ikan bandeng yang dibeli oleh konsumen dalam waktu satu bulan. Permintaan berbeda-beda pada masing-masing konsumen disebabkan oleh kebutuhan, daya beli dan selera konsumen. Jawaban konsumen sampel mengenai jumlah permintaan ikan bandeng dalam waktu satu bulan disajikan pada tabel V-3 berikut.

Tabel V-3. Rata-Rata Permintaan Konsumen Ikan Bandeng di Pasar Peureulak, 2017

\begin{tabular}{|l|l|c|}
\hline No & \multicolumn{1}{|c|}{ Konsumen Dari Pedagang } & Permintaan (Kg/Bulan) \\
\hline 1 & Lorong I & 4.90 \\
2 & Lorong II & 5.82 \\
3 & Lorong III & 5.44 \\
\hline \multicolumn{2}{|l|}{ Rata-rata } & 5.40 \\
\hline
\end{tabular}

Sumber : Data Primer, 2017 (diolah) 
Tabel V-3 di atas dapat dilihat bahwa rata-rata permintaan konsumen ikan bandeng di Pasar Peureulak sebesar 5,4 kg/bulan. Permintaan tertinggi terdapat pada konsumen ikan bandeng yang berasal dari pedagang ikan bandeng Lorong II sebesar $5,82 \mathrm{~kg} /$ bulan, sedangkan permintaan terendah adalah pada konsumen yang berasal dari pedagang ikan bandeng Lorong I sebesar 4,9 kg/bulan.
Harga Ikan Bandeng

Harga ikan bandeng adalah sejumlah uang yang dibayarkan konsumen pada saat membeli ikan bandeng perkilogram di pedagang pengecer. Harga ikan bandeng tidak sama disebabkan oleh ukuran ikan, asal ikan dan modal yang dikeluarkan oleh pedagang pengecer. Rata-rata harga ikan bandeng yang dibeli konsumen di Pasar Peureulak disajikan pada tabel V-4 berikut.

Tabel V-4. Rata-Rata Harga Ikan Bandeng Yang Dibeli Konsumen di Pasar Peureulak, 2017

\begin{tabular}{|l|l|c|}
\hline No & \multicolumn{1}{|c|}{ Konsumen Dari Pedagang } & Harga $(\mathrm{Rp} / \mathrm{Kg})$ \\
\hline 1 & Lorong I & $22.300,00$ \\
2 & Lorong II & $24.454,55$ \\
3 & Lorong III & $24.444,44$ \\
\hline \multicolumn{2}{|l|}{ Rata-rata } & $23.733,33$ \\
\hline
\end{tabular}

Sumber : Data Primer, 2017 (diolah)

Tabel V-4 di atas dapat dilihat rata-rata harga ikan bandeng yang dibeli konsumen di Pasar Peureulak adalah Rp. 23.733,33/Kg. Harga tertinggi terdapat pada konsumen yang berasal dari pedagang Lorong II sebesar Rp. $24.454,55 / \mathrm{Kg}$ dan harga terendah terdapat pada konsumen yang berasal dari pedagang Lorong I sebesar Rp. 22.300/Kg. Perbedaan harga yang terjadi karena ukuran ikan yang berbeda pada masing-masing pedagang. Semakin besar ikan bandeng maka harganya semakin mahal sedangkan semakin kecil ukuran ikan bandeng maka harganya semakin murah. Perbedaan harga juga terjadi karena asal ikan bandeng karena ikan bandeng yang Tabel V-5. Rata-Rata Skor Jawaban Konsumen Ikan Bandeng Atas Pertanyaan Selera Konsumen di Pasar Peureulak, 2017

\begin{tabular}{|l|l|c|}
\hline No & \multicolumn{1}{|c|}{ Konsumen Dari Pedagang } & Selera (Skor) \\
\hline 1 & Lorong I & 2.20 \\
2 & Lorong II & 2.18 \\
3 & Lorong III & 2.22 \\
\hline \multicolumn{2}{|l|}{ Rata-rata } & 2.20 \\
\hline
\end{tabular}

Sumber : Data Primer, 2017 (diolah)

Tabel V-5 di atas dapat dilihat bahwa rata-rata skor jawaban konsumen ikan bandeng di Pasar Peureulak adalah 2,2 skor yang berarti selera konsumen adalah sedang menuju tinggi. Skor tertinggi terdapat pada konsumen yang berasal dari pedagang Lorong III sebesar 2,22 skor dan skor terendah terdapat pada konsumen yang berasal dari pedagang Lorong II sebesar Rp. 2,18 skor. berasal dari Aceh Utara terkenal enak maka harganya lebih mahal. Kemudian perbedaan harga ikan bandeng juga disebabkan oleh modal yang dikeluarkan untuk membeli ikan bandeng oleh pedagang juga berbeda-beda.

\section{Selera Konsumen}

Selera konsumen atas ikan bandeng juga berbeda-beda disebabkan oleh beberapa hal yaitu rasa gurih, kesegaran, kandungan gizinya, budaya dan dapat diolah menjadi berbagai masakan. Rata-rata skor jawaban konsumen ikan bandeng atas pertanyaan mengenai selera konsumen di Pasar Peureulak dapat dilihat pada tabel V-5 berikut ini.

\section{Pendapatan Konsumen Ikan Bandeng}

Pendapatan ini adalah pendapatan konsumen yang diterima dari pekerjaannya dalam waktu satu bulan. Bagi konsumen yang mempunyai pekerjaan pegawai, guru atau karyawan tentunya didasarkan pada gaji perbulan yang diterima sedangkan konsumen dengan pekerjaan petani maka pendapatan adalah pengahsilan rata-rata perbulan dari usahatani yang dikelolanya. Pendapatan 
Tabel V-6. Rata-Rata Pendapatan Konsumen Ikan Bandeng di Pasar Peureulak, 2017

\begin{tabular}{|l|l|c|}
\hline No & \multicolumn{1}{|c|}{ Konsumen Dari Pedagang } & Pendapatan (Rp/Bulan) \\
\hline 1 & Lorong I & $2.230 .000,00$ \\
2 & Lorong II & $2.463 .636,36$ \\
3 & Lorong III & $2.261 .111,11$ \\
\hline \multicolumn{2}{|l|}{ Rata-rata } & $2.325 .000,00$ \\
\hline
\end{tabular}

Sumber : Data Primer, 2017 (diolah)

Tabel V-4 di atas dapat dilihat rata-rata pendapatan konsumen ikan bandeng di Pasar Peureulak adalah Rp. 2.325.000/Bulan. Pendapatan tertinggi terdapat pada konsumen yang berasal dari pedagang Lorong II sebesar Rp. 2.463.636,36/Bulan dan pendapatan terendah terdapat pada konsumen yang berasal dari pedagang Lorong I sebesar $\mathrm{Rp}$. 2.230.000/Bulan.

Pengaruh Harga, Selera Konsumen dan Pendapatan Konsumen Terhadap Permintaan Ikan Bandeng Di Pasar Peureulak Kabupaten Aceh Timur

Untuk menganalisis pengaruh harga, selera konsumen dan pendapatan konsumen terhadap permintaan ikan bandeng di Pasar Peureulak digunakan model analisis regresi linier berganda. Hasil analisis linier berganda diperoleh persamaan regresi sebagai berikut: $Y=-1,102+0,119 X_{1}+0,146 X_{2}+1,439 X_{3}$ Dengan interprestasi sebagai berikut:

- Koefisien regresi faktor harga ikan bandeng $\left(\mathrm{X}_{1}\right)$ sebesar 0,119. Artinya bila selera konsumen dan pendapatan konsumen dianggap tetap maka setiap penambahan harga ikan bandeng sebesar Rp 10.000/Kg akan menyebabkan permintaan ikan bandeng meningkat sebesar 0,119 $\mathrm{Kg} /$ bulan.
- Koefisien regresi faktor selera konsumen $\left(\mathrm{X}_{2}\right)$ sebesar 0,146 . Artinya bila harga dan pendapatan konsumen dianggap tetap maka setiap penambahan selera konsumen sebesar 1 skor akan menyebabkan permintaan ikan bandeng meningkat sebesar 0,146 Kg/Bulan.

- Koefisien regresi faktor pendapatan $\left(X_{3}\right)$ sebesar 1,439. Artinya bila harga dan selera konsumen dianggap tetap maka setiap penambahan pendapatan konsumen sebesar Rp 1.000.000,-/Bulan akan menyebabkan permintaan ikan bandeng meningkat sebesar 1,439 Kg/Bulan.

\section{Uji $\mathbf{R}^{2}$ (Koefisien Determinasi)}

Hasil analisis data secara regresi linier berganda menghasikan nilai $\mathrm{R}^{2}$ sebesar 0,69 artinya bahwa variabel harga $\left(\mathrm{X}_{1}\right)$, selera konsumen $\left(\mathrm{X}_{2}\right)$ dan pendapatan konsumen $\left(\mathrm{X}_{3}\right)$ mempengaruhi permintaan ikan bandeng (Y) di Pasar Peureulak sebesar $69 \%$. Sisanya sebesar $31 \%$ dipengaruh faktor lain yang tidak dimasukan dalam model penelitian ini.

\section{Uji F (Pengaruh Simultan)}

Hasil pengujian pengaruh serempak disajikan pada Tabel V.8 berikut:

Tabel V.7. Hasil Regresi Uji F

\begin{tabular}{|l|l|l|l|l|}
\hline \multirow{2}{*}{$\mathrm{F}_{\text {cari }}$} & $\mathrm{F}_{\text {tabel }}$ & Kesimpulan \\
\cline { 2 - 4 } & $\alpha=0,05$ & $\alpha=0,01$ & \\
\hline 19,278 & 2,95 & 4,59 & $\begin{array}{l}\mathrm{F}_{\text {cari }}>\mathrm{F}_{\text {tabel }} \quad \alpha=0,05 \quad \text { dan } \\
\alpha=0,01\end{array}$ \\
\hline
\end{tabular}

Sumber : Data Primer, 2017 (diolah)

Tabel di atas menunjukkan hasil analisis data secara regresi linier berganda diperoleh nilai $F_{\text {cari }}$ sebesar 19,278 . Nilai $F_{\text {tabel }}$ adalah 4,50 $(\alpha=0,01)$ dan $2,90(\alpha=0,05)$. Berarti $F_{\text {cari }}>$ dari $\mathrm{F}_{\text {tabel }}$ pada tingkat keyakinan $95 \%$ dan $99 \%$. Artinya secara serempak variabel harga $\left(\mathrm{X}_{1}\right)$, selera konsumen $\left(\mathrm{X}_{2}\right)$ dan pendapatan konsumen $\left(\mathrm{X}_{3}\right)$ secara serempak berpengaruh AGRISAMUDRA, Jurnal Penelitian Vol. 4 No.2 Julii - Desember 2017 sangat nyata terhadap permintaan ikan bandeng (Y) di Pasar Peureulak.

Dengan demikian;

- $\mathrm{H}_{0}$ hipotesis yang menyatakan secara serempak harga $\left(\mathrm{X}_{1}\right)$, selera konsumen $\left(\mathrm{X}_{2}\right)$ dan pendapatan konsumen $\left(\mathrm{X}_{3}\right)$ secara serempak tidak berpengaruh nyata 
terhadap permintaan ikan bandeng (Y) di Pasar Peureulak, ditolak

- $\mathrm{H}_{1}$ hipotesis yang menyatakan secara serempak harga $\left(\mathrm{X}_{1}\right)$, selera konsumen $\left(\mathrm{X}_{2}\right)$ dan pendapatan konsumen $\left(\mathrm{X}_{3}\right)$ secara serempak berpengaruh nyata terhadap permintaan ikan bandeng (Y) di Pasar Peureulak, diterima

\section{Uji t (Pengaruh Terpisah)}

Hasil pengujian pengaruh terpisah disajikan pada Tabel V.9 berikut:

Tabel V.9. Hasil Regresi Uji t

\begin{tabular}{|l|l|l|l|l|l|}
\hline Variabel & $\mathrm{t}_{\text {cari }}$ & $\mathrm{t}_{\text {tabel }}$ & Keterangan & $\begin{array}{l}\text { Kesimpulan } \\
\text { Pengaruh }\end{array}$ \\
\cline { 3 - 5 } & 1,108 & 1,712 & 2,47 & $\begin{array}{l}\mathrm{t}_{\text {cari }}<\mathrm{t}_{\text {tabel }} \text { pada } \\
\alpha=0,05\end{array}$ & $\begin{array}{l}\text { Tidak } \\
\text { Berpengaruh }\end{array}$ \\
\hline Selera $\left(\mathrm{X}_{2}\right)$ & 0,306 & 1,712 & 2,47 & $\begin{array}{l}\mathrm{t}_{\text {cari }}<\mathrm{t}_{\text {tabel }} \text { pada } \\
\alpha=0,05 \quad\end{array}$ & $\begin{array}{l}\text { Tidak } \\
\text { Berpengaruh }\end{array}$ \\
\hline Pendapatan $\left(\mathrm{X}_{3}\right)$ & 2,611 & 1,712 & 2,47 & $\begin{array}{l}\mathrm{t}_{\text {cari }}>\mathrm{t}_{\text {tabel }} \text { pada } \\
\alpha=0,05 \text { dan } 0,01\end{array}$ & $\begin{array}{l}\text { Berpengaruh } \\
\text { Sangat Nyata }\end{array}$ \\
\hline
\end{tabular}

Sumber: Data Primer Diolah, 2017

Tabel di atas menunjukkan hasil analisis data secara regresi linier berganda diperoleh hasil sebagai berikut:

- Nilai $t_{\text {cari }} X_{1}$ (harga) sebesar 1,108, artinya $t_{\text {cari }}<$ dari $t_{\text {tabel }}$ pada tingkat keyakinan 95\%, sehingga disimpulkan bahwa secara terpisah harga tidak berpengaruh terhadap permintaan ikan bandeng di Pasar Peureulak Kabupaten Aceh Timur.

- $\quad t_{\text {cari }} X_{2}$ (selera) sebesar 0,306 artinya $\mathrm{t}_{\text {cari }}<$ dari $\mathrm{t}_{\text {tabel }}$ pada tingkat keyakinan 95\% sehingga disimpulkan bahwa secara terpisah selera konsumen tidak berpengaruh terhadap permintaan ikan bandeng di Pasar Peureulak Kabupaten Aceh Timur.

- $t_{\text {cari }} X_{3}$ (pendapatan) sebesar 2,611, artinya $t_{\text {cari }}>$ dari $t_{\text {tabel }}$ pada tingkat keyakinan 95\% sehingga disimpulkan bahwa secara terpisah pendapatan konsumen berpengaruh sangat nyata terhadap permintaan ikan bandeng di Pasar Peureulak Kabupaten Aceh Timur.

\section{KESIMPULAN DAN SARAN Kesimpulan}

1. Hasil analisis linier berganda diperoleh persamaan regresi sebagai berikut: $\mathrm{Y}=-1,102+0,119 \mathrm{X}_{1}+$ $0,146 \mathrm{X}_{2}+1,439 \mathrm{X}_{3}$

2. Hasil analisis data secara regresi linier berganda menghasikan nilai $\mathrm{R}^{2}$ sebesar 0,69 artinya bahwa variabel harga $\left(\mathrm{X}_{1}\right)$, selera konsumen $\left(\mathrm{X}_{2}\right)$ dan pendapatan konsumen $\left(\mathrm{X}_{3}\right)$ AGRISAMUDRA, Jurnal Penelitian Vol. 4 No.2 Julii-Desember 2017 mempengaruhi permintaan ikan bandeng (Y) di Pasar Peureulak sebesar $69 \%$. Sisanya sebesar 31\% dipengaruh faktor lain yang tidak dimasukan dalam model penelitian ini.

3. Secara serempak variabel harga $\left(X_{1}\right)$, selera konsumen $\left(\mathrm{X}_{2}\right)$ dan pendapatan konsumen $\left(\mathrm{X}_{3}\right)$ secara serempak berpengaruh sangat nyata terhadap permintaan ikan bandeng (Y) di Pasar Peureulak.

4. Secara terpisah harga dan selera konsumen tidak berpengaruh nyata terhadap permintaan ikan bandeng, sedangkan pendapatan konsumen secara terpisah berpengaruh sangat nyata terhadap permintaan ikan bandeng di Pasar Peureulak Kabupaten Aceh Timur.

\section{Saran-saran}

1. Diharapkan kepada konsumen ikan bandeng agar tetap mengkosumsi ikan bandeng karena kandungan gizi yang tinggi, harga terjangkau dan memiliki variasi kualitas.

2. Perlu adanya inovasi pengolahan ikan bandeng menjadi bentuk olahan yang beragam sehingga konsumen dapat membeli dengan berbagai kebutuhan baik dikonsumsi langsung maupun disimpan sebagai cadangan makanan.

\section{DAFTAR PUSTAKA}

Anonimous, 2013. Olahan Ikan Bandeng. http://anggriandika.wordpress.com 
/2010/05/23/olahan-ikan-bandeng (di akses tanggal 23 april 2015, jam 08.30 wib)

Fajar subhan falah's, 2013. Faktor yang Mempengaruhi Permintaan. http : // fajar falah. blogspot. Com / 2013 0301 archive.html (di akses tanggal 29 juli 2015, jam 09:15 wib

Firdaus, 2009. Manajemen Agribisnis, Bumi Aksara, Jakarta.

Hasan Ismail, 2009. Pengertian Respon. (http://hasanismailr.blogspot. com/2009/06/pengertian respon.html). (diakses tanggal 3 Juli 2015) jam 08:30 WIB.

Ibnu, M. Budidaya Ikan Bandeng dengan Memanfaatkan Limbah Mie Instan. Cipta Media Binanusa, Jakarta.

Irul, 2010. Permintaan, Penawaran, Harga dan Keseimbangan. http : // www. irulazzyboy.blogspot.com. html (di akses tanggal 18 Agustus 2015, jam 13:00 wib)

Mursid. 2003. Teori Dasar Harga dan Pasar Hasil Pertanian. Warta Intra. Jakarta.

Nana, 2005. Metode Penelitian,Tarsito, Bandung.

Nazir, Mohammad 2009, Metode Penelitian, Edisi Ketujuh, Ghalia Indonesia

Prahasta, A. dan Hasanawi M. 2009. Agribisnis Bandeng. Pustaka Grafika, Bandung

Raihanah. 2014. Potensi Kelautan dan Perikanan Aceh. http://www. Potensikelautan-dan-perikanan-

Aceh.com/artikel/aceh.tribunews.com. . (di akses tanggal 25 November 2015, jam 09.35 wib)

Sandra,p. 2011. Pengertian Respon.http : //pratamasandra. Wordpress. Com.

Sanjaya

www.sarjanaku.com/2013/04/pengerti

an-harga-menurut-para ahli.html (diakses tanggal 20 oktoer 2015)

Samuelson dan Nardhaus. 1997. Jurnal Pendapatan. Http : // repository. unhas. ac. id/bitstream/handle/123456789/.../BA B\%20II.docx? (diakses pada tanggal 18 maret 2015)

Sudjana, 2003. Buku Penelitian dan Penilaian. Sinar Baru, Bandung.

Sudjana. 2005, Metoda Statistika. Tarsito Bandung.
Sugiyono, 2010, Metode Penelitian Kuantitatif Kualitatif $R$ dan $D$, Alfabeta, Bandung.

Sulaksono, S. 2013. Kandungan Nutrisi dan Manfaat Ikan Bandeng Untuk Kesehatan.

http://www.carakhasiatmanfaat.com/ar tikel/kandungan-nutrisi-manfaat-ikanbandeng.html. (di akses tanggal 25 maret 2015, jam $09.35 \mathrm{wib}$ )

Winardi, 1997. Azas-Azas Marketing, Alumni, Bandung. 